\title{
A MAGYAR MEZŐGAZDASÁG TELJESÍTMÉNYE 2004-2017 KÖZÖTT
}

\author{
Popp József - Szenderák János - Fróna Dániel - Felföldi János - Oláh Judit - \\ Harangi-Rákos Mónika
}

\begin{abstract}
Absztrakt: Magyarországon a mezőgazdasági ágazat nemzetgazdasági szerepe az uniós csatlakozás után sem változott meg, 2004-2017 között a mezőgazdaság részaránya a GDP termelésben 3,0- 4,1\% között ingadozott. A mezőgazdaság húzóágazata a növénytermesztés, így a teljesítményt nagyban meghatározza a növénytermesztési ágazat évenkénti kibocsátása és a növényi termékek áralakulása. Az ágazat beruházása a támogatási lehetőségekhez igazodott, ezért követi annak ciklikusságát. A mezőgazdasági beruházások részesedése az ország összes beruházásából 2000-ben 4,7\%-ot tett ki, 2014-ben érte el a legmagasabb, 6\%-os arányt, azóta viszont csökkent a beruházási kedv. A mezőgazdasági kibocsátás 2016-ban megközelítette a 2600 milliárd forintot, a kibocsátás és a folyó termelöfelhasználás különbözeteként számított bruttó hozzáadott érték pedig az 1100 milliárd forintot. A fizetett munkaerő-ráfordítás évek óta emelkedik, a teljes felhasznált munkaerő-mennyiség pedig csökken. A jövedelmek forrása a termelői áron számított bruttó hozzáadott érték mellett a növénytermesztés terméktámogatása, az állatok és állati termékek terméktámogatása és az egyéb termelési támogatások - termelési adókkal csökkentett - összege. A termelési tényezők (felhasznált föld, tőke, munkaerő) jövedelme az elmúlt években föként a növénytermesztés hozamaitól és a termelöi áraktól függően változott, ami a vállalkozói jövedelem alakulását is meghatározta. Ezzel szemben a felhasználási oldalon szereplő költségek (munkadíj, bérleti díj és kamat) és az értékcsökkenésre elszámolt összeg kevésbé ingadozott. Magyarországon az EU-csatlakozás után a mezőgazdasági vállalkozók jövedelmén belül nőtt a támogatások aránya. Az időjárástól függő kibocsátás ingadozása is számottevően befolyásolja a jövedelem alakulását. A jó terméshozamú években a jövedelem összetételében a támogatások szerepe csökken. 2016-ban 73\% volt ez az arány, de a kevésbé jó termést hozó években ennél magasabb arányt tett ki a támogatás a vállalkozói jövedelmekben.
\end{abstract}

Abstract: In Hungary, the role of the agricultural sector in the national economy has not changed since the country's accession to the EU; between 2004 and 2017 the share of agriculture in GDP varied between 3.0 and $4.1 \%$. The driving force within the agricultural sector is crop production, so performance is largely determined by the annual output of the crop production sector and the varying prices of crops. The investment of the sector is adjusted to the financial support options available and therefore follows its cyclical nature. Agricultural investments accounted for $4.7 \%$ of total investment in the country in 2000, and reached a maximum of $6 \%$ in 2014; since then, however, investment as an activity has become less attractive. In 2016, agricultural output approached 2,600 billion forints, while the gross added value of the difference between output and current consumption was 1100 billion forints. Paid labour costs have been rising for many years, although the total amount of labour employed is decreasing. The source of income includes - besides the gross added value at producer prices - coupled support for crop production, coupled support for livestock and animal products and other subsidies for production, reduced by production taxes. The income of production factors (land used, capital, and labour) has changed in recent years, mainly as a result of crop yields and producer prices, which has also determined changes in entrepreneurial income. By contrast, the costs on the user side (labour, rent and interest) and the amount depreciated have fluctuated to a lesser extent. In Hungary, after accession to the EU, the proportion of subsidies in the income of agricultural farms increased. Weather-dependent fluctuations in output also have a significant impact on income trends. In good yield years, the role of subsidies in total income decreases. In 2016 this proportion was 73\%, but in years with lower yields, the proportion of subsidies in farms' income was higher.

Kulcsszavak: támogatás, mezőgazdaság, munkaerő-felhasználás, régió

Keywords: support, agriculture, labour force use, region 


\section{Bevezetés}

Magyarország 2004. május 1-jén csatlakozott az Európai Unióhoz. Tudatosult, hogy az információ és a rendelkezésre álló tudás szerepe is meghatározó a hatékonyság növelésében a hirtelen változó piaci körülmények keretei között (Kapronczai et al., 2005). A csatlakozást követő években beigazolódott, hogy a mezőgazdaság szereplöi nem voltak felkészülve arra, hogy az Európai Unió tagjává váljanak (Popp et al., 2007). A csatlakozás után szembe kellett nézni a korábbi versenyképesség gyengeségeivel, mint például az alacsony szervezettség és felszereltség, a korszerủtlen technológia és a hiányos logisztikai rendszerek alkalmazása, továbbá az elavult birtokstruktúra (Botos et al., 2015). Ezek a gyengeségek igazán akkor kerültek előtérbe, amikor „,váratlanul” erős versennyel találtuk szembe magunkat, itthon piacot vesztettünk, strukturális feszültségek alakultak ki és túlzottan sokan estek ki a termelésből (Udovecz, 2007).

Az EU-csatlakozás előtt a szakértők a magyar mezőgazdaság tőkehiányát tartották az első számú versenyképességi problémának a régi tagállamok gazdáival szemben. Az EU-csatlakozás óta jelentős biológiai és technikai fejlődés ment végbe, ennek ellenére Magyarország közel sem használja ki ökológiai adottságait a mezőgazdaságban. A megfelelő stratégia jelenlétét tehát a hosszú távú fenntarthatóság és a versenyelőnyök megszerzésének, illetve azok fenntartásának alapvető eszközeként tarthatjuk számon (Popp et al., 2017a).

A mezőgazdaság erősen támogatott ágazat, de a globális népesség növekedésével párhuzamosan az élelmiszer iránti kereslet folyamatosan nő (Botos et al., 2018). Mindez felértékeli a mezögazdaság szerepét, ugyanakkor befektetés szempontjából csak akkor marad vonzó, ha képes alkalmazkodni a folyamatos változásokhoz. Az EU 2020 stratégiája a versenyképesség, az innováció, a hatékonyság javításának követelményét fogalmazza meg. Ez azt jelenti, hogy a korszerü technika, technológia alkalmazása növekvő termésátlagokkal és csökkenő fajlagos költségekkel párosul (Herdon et al., 2015).

Jelenleg sem piaci, sem támogatási oldalról nem látható a szerkezetváltás képe, ezért a közeljövőben nem várható a mai termelési struktúra átalakítása (Popp et al., 2017b). Az uniós források erősen befolyásolják a magyarországi beruházásokat. 2009 és 2016 között az uniós források felhasználásának mértéke évente GDParányosan közel 4\%-ot tett ki, ami az egyik legmagasabb arány az EU-ban (KPMGGKI, 2017). Az uniós támogatás magas szintje függőségi kultúrát teremt, mivel kisebb kockázattal jár a kedvezményezett számára és a termelékeny vállalkozások használták fel kapacitásbővítésre a technológiai fejlesztés helyett (Banai et al., 2017). Az üzleti beruházásokra főként a nagy és külföldi tulajdonú vállalatoknál került sor, különösen az exportágazatokban (Kopint-Tárki, 2017). 


\section{Eredmények és azok értékelése}

\subsection{Magyarország mezőgazdasága 2004 és 2017 között}

Az ágazat nemzetgazdasági szerepe az uniós csatlakozás után sem változott meg, ugyanis a mezőgazdaság részaránya a bruttó hazai termék (GDP: Gross Domestic Product) termelésében érdemben nem változott meg (1. táblázat).

\section{1. táblázat: Az agrárgazdaság aránya a nemzetgazdaságban (folyó áron)}

\begin{tabular}{|c|c|c|c|}
\hline \multirow{2}{*}{$\mathbf{E} \mathbf{v}$} & \multicolumn{3}{|c|}{ A mezőgazdaság részaránya (a) } \\
\cline { 2 - 4 } & $\begin{array}{c}\text { a } \\
\text { foglalkoztatásban } \\
\text { (b) } \\
\text { \% }\end{array}$ & GDP termelésben & a beruházásban \\
\cline { 2 - 4 } & 5,5 & \multicolumn{2}{|c|}{ folyó áron, \% } \\
\hline $\mathbf{2 0 0 3}$ & 5,3 & 3,7 & 6,1 \\
\hline $\mathbf{2 0 0 4}$ & 5,0 & 4,1 & 4,3 \\
\hline $\mathbf{2 0 0 5}$ & 4,9 & 3,7 & 4,5 \\
\hline $\mathbf{2 0 0 6}$ & 4,7 & 3,5 & 4,2 \\
\hline $\mathbf{2 0 0 7}$ & 4,4 & 3,4 & 3,7 \\
\hline $\mathbf{2 0 0 8}$ & 4,7 & 3,4 & 4,7 \\
\hline $\mathbf{2 0 0 9}$ & 4,6 & 3,0 & 5,6 \\
\hline $\mathbf{2 0 1 0}$ & 4,9 & 3,0 & 4,8 \\
\hline $\mathbf{2 0 1 1}$ & 5,0 & 3,9 & 5,6 \\
\hline $\mathbf{2 0 1 2}$ & 4,7 & 3,8 & 5,8 \\
\hline $\mathbf{2 0 1 3}$ & 4,6 & 3,9 & 5,9 \\
\hline $\mathbf{2 0 1 4}$ & 4,8 & 4,0 & 6,0 \\
\hline $\mathbf{2 0 1 5}$ & 5,0 & 3,7 & 4,8 \\
\hline $\mathbf{2 0 1 6}$ & 5,0 & 3,7 & 5,0 \\
\hline $\mathbf{2 0 1 7}$ & 3,3 & 4,8 \\
\hline
\end{tabular}

a) Mezögazdaság, erdögazdálkodás, halászat ágba sorolt gazdasági szervezetek. b) A munkaerö-felmérés adatai.

Forrás: KSH (2018)

A pénzügyi válság reálgazdasági hatásai következtében 2008 végére a világ meghatározó országainak gazdasága recesszióba fordult. A mezőgazdaság GDP részesedése 2009-ben és 2010-ben tovább csökkent, amiben a növényi termékek és a tej nagyarányú áresése is közrejátszott. A 2011. évi adatok alapján a mezőgazdaság kiemelkedő évet zárt és mind a kibocsátás volumene, mind pedig a termelői árszínvonal számottevően emelkedett, ennek eredményeként az ágazat nemzetgazdasági súlya 0,9 százalékponttal nőtt az előző évhez képest. 
A mezőgazdaság részaránya a GDP előállításából nem ért el érzékelhető növekedést 2010 óta, ugyanis aránya továbbra is 3,3\%-4,0\% között alakult az egyes években. A 2017-es előzetes adatok szerint a mezőgazdaság a GDP-hez 3,3\%-kal járult hozzá, ami csökkenést mutat az elöző évekhez képest. A beruházásokban 4,8\% és a foglalkoztatásban 5,0\% volt a szektor aránya 2017-ben, vagyis nem változott számottevő mértékben az előző évhez viszonyítva (KSH, 2018).

A mezőgazdaság bruttó termelési értékéről elmondható, hogy az EU-csatlakozás évében volt a legmagasabb. 2004 és 2007 között a kibocsátás értéke csökkent, de 2008-ban újra nőtt a növénytermesztés növekvő kibocsátásának köszönhetően. A mezőgazdaság kibocsátásának értéke csak 2016-ban tudta megközelíteni a 2004. évi értéket. 2015-2017 között a mezőgazdaság bruttó termelési értéke lényegében stagnált. Fontos kiemelni, hogy a mezőgazdaság húzóágazata a növénytermesztés, így a mezőgazdaság teljesítményét nagyban meghatározza a növénytermesztési ágazat évenkénti kibocsátása (KSH, 2018).

A mezőgazdaságban az eszközfelszereltség (álló- és forgóeszközök) ellentmondásos képet mutat. Míg az állóeszköz-felszereltség - épületek, építmények/gépek, berendezések, jármüvek - változatlan áron vizsgálva az EUcsatlakozást követő évek egyikében sem érte el a 2003-as szintet (a magas beruházási támogatásnak köszönhetően), addig a forgóeszközök egy hektárra vetített értéke nőtt. A forgóeszköz-ellátottság azonban a társas és egyéni gazdaságokban jelentős eltéréseket mutat. Míg az utóbbinak fajlagosan nagyobb az igénye a gépek, berendezések iránt, addig a forgóeszköz készletek a társas gazdaságok esetében mutatnak kiemelkedő értéket. Az EU-csatlakozást követő években visszaesés volt tapasztalható annak köszönhetően, hogy az új támogatási rendszer megjelenésével a beruházási támogatások már nem játszottak akkora szerepet. A beruházási lehetőségeket a társas gazdaságok a támogatási preferenciából adódóan hamarabb ki tudták használni. Nem lehet megkerülni a mérethatékonyság, a méretoptimum kérdését (Gazdag, 2003).

Az ágazat beruházási tevékenységére jellemző, hogy annak nagysága a támogatási lehetőségekhez igazodott, ezért követi annak ciklikusságát. A mezőgazdasági beruházások részesedése az ország összes beruházásából 2000-ben 4,7\%-ot tett ki, a következő évek számottevő ingadozása után 2014-ben érte el a legmagasabb, 6,0\%-os arányt. Utána csökkent a beruházási kedv, 2017-ben az előzetes adatok szerint a nemzetgazdaság összes beruházásából a mezőgazdaság, az erdőgazdálkodás és a halászati ágazat 4,8\%-kal, az élelmiszeripar 3,1\%-kal részesedett. A teljes nemzetgazdaság beruházási volumene 17\%-kal, a mezőgazdaságé 12\%-kal nőtt 2017-ben. A beruházások összetételéről elmondható, hogy 56\%-át a gépek, 19\%-át az épületek tették ki. Az előbbiek volumene 23\%-kal, az utóbbiaké 2,8\%-kal bővült az előző évhez képest (KSH, 2018).

\subsection{A ráfordítások volumene és értéke emelkedett}

A mezőgazdaság teljes kibocsátása az ágazat termeléséről, a felhasználásról a ráfordítások, azaz a folyó termelőfelhasználás nyújt információt. A termelőfelhasználás mindazoknak az áruknak és szolgáltatásoknak az értéke, 
amelyeket a termelési folyamat során a gazdaságok felhasználnak. 2016-ban a termékek elöállítására és a szolgáltatások nyújtására fordított folyó termelőfelhasználás 1513 milliárd forint volt (piaci beszerzési áron). A kibocsátás és termelőfelhasználás különbözeteként elszámolt bruttó hozzáadott érték 1074 milliárd forintot tett ki. 2000 óta megállapítható, hogy a növénytermesztéssel kapcsolatos ráfordítások aránya a teljes folyó termelőfelhasználáson belül emelkedett, de a mütrágyák, a növényvédő szerek és a vetőmagok aránya is nőtt. Ezzel ellentétben az állati takarmányok a teljes összegböl csökkenő arányt mutatnak. A folyó termelőfelhasználás megoszlását vizsgálva látható, hogy 2016-ban 31\%-kal az állati takarmányok részesedése volt a legnagyobb, majd 13\%-os részesedéssel az energia és kenőanyagok, $10 \%$-os részaránnyal pedig a mütrágya és talajjavítószer következett. A mezőgazdasági szolgáltatási díjak a növényvédő szer, a vetőmag és palánta, valamint a gépfenntartási költségek aránya 6-9\% között mozogtak (1. ábra).

\section{1. ábra: A folyó termelőfelhasználás összetétele 2016-ban (folyó alapáron)}

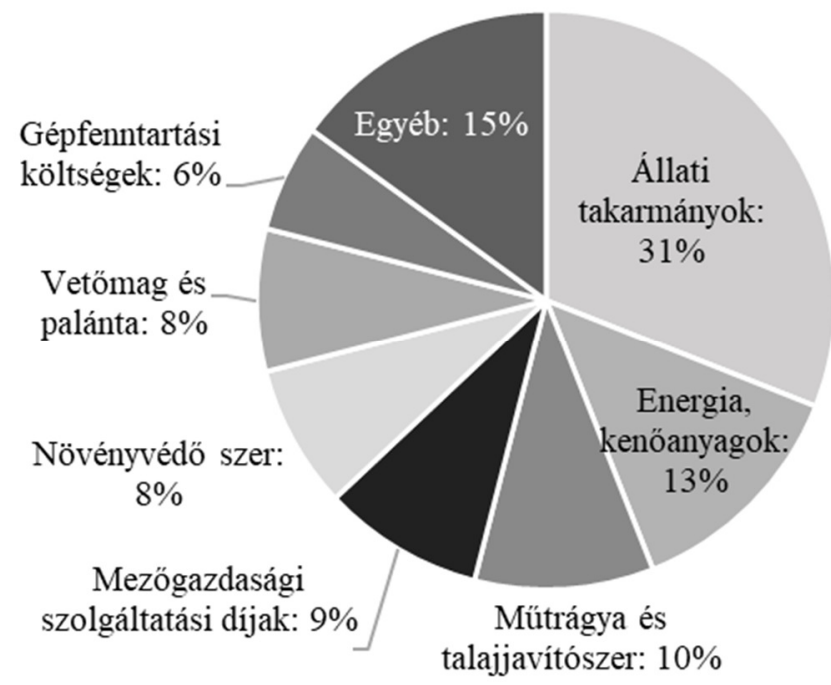

Forrás: KSH (2017) adatai alapján saját szerkesztés

A kibocsátás és a folyó termelőfelhasználás különbözeteként kalkulált bruttó hozzáadott érték 2016-ban folyó áron 1074 milliárd forint volt. A teljes kibocsátáson belül a bruttó hozzáadott érték aránya 42\%-ot tett ki, azaz 100 forint kibocsátáshoz 58 forint ráfordításra volt szükség. A bruttó hozzáadott érték aránya 2009 és 2016 között 29\%-ról 42\%-ra emelkedett (2. ábra). 
2. ábra: A kibocsátás összetétele (folyó alapáron)

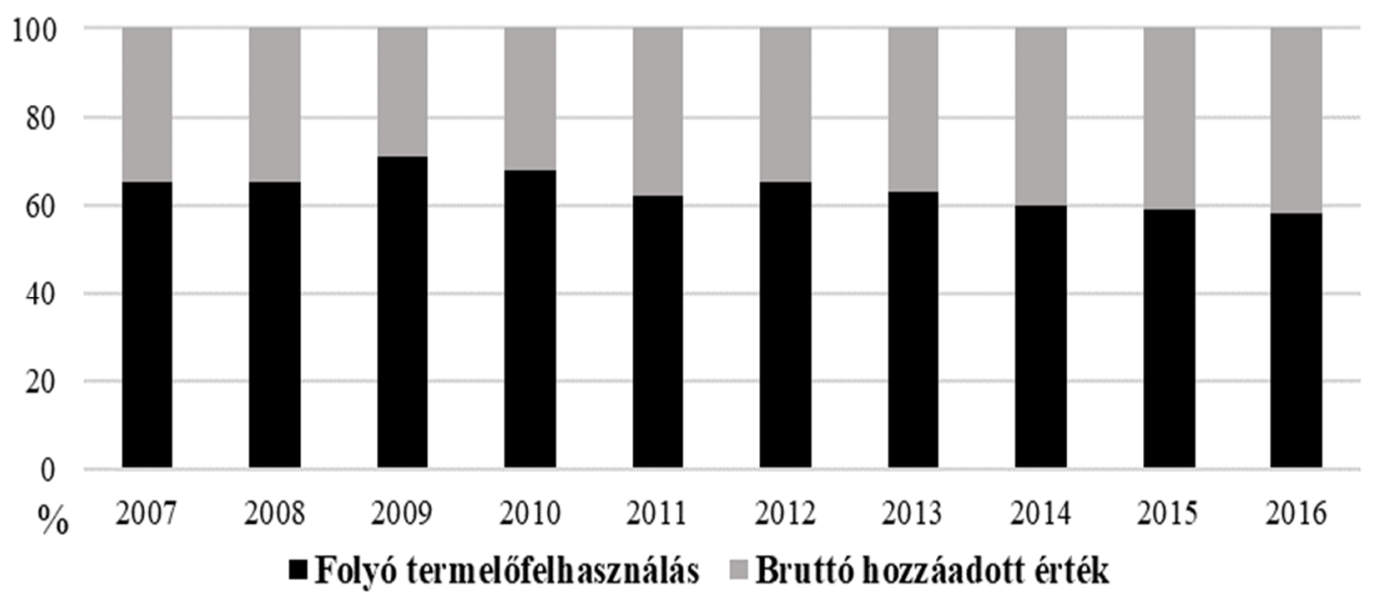

Forrás: KSH (2017) adatai alapján saját szerkesztés

A termelési támogatások nettó összege 2016-ban 515 milliárd forintot ért el. 2015-ben az agrártámogatás rendszer szerkezete megváltozott. Magyarország az EU-csatlakozás után az agrártámogatások termékekhez köthető (ezáltal a bruttó hozzáadott értéket növelö) hányada folyamatosan csökkent (2004 és 2014 között évi 44\%-ról 6,6\%-ra), miközben a termékhez nem köthető (például földalapú, vidékfejlesztési) támogatások - a termelési tényezők jövedelmét növelik - aránya fokozatosan emelkedett. 2015-től viszont ismét nagyobb szerepet kaptak a terméktámogatások a tagállamok mozgásterének bővítése érdekében. Magyarország a rendelkezésre álló termeléshez kötött támogatási keretet teljes egészében felhasználja. A növénytermesztési és az állattenyésztési támogatások mértéke is többszörösére emelkedett a korábbi évekhez viszonyítva (3. ábra).

\section{3. ábra: A termelési támogatások összetételének alakulása}

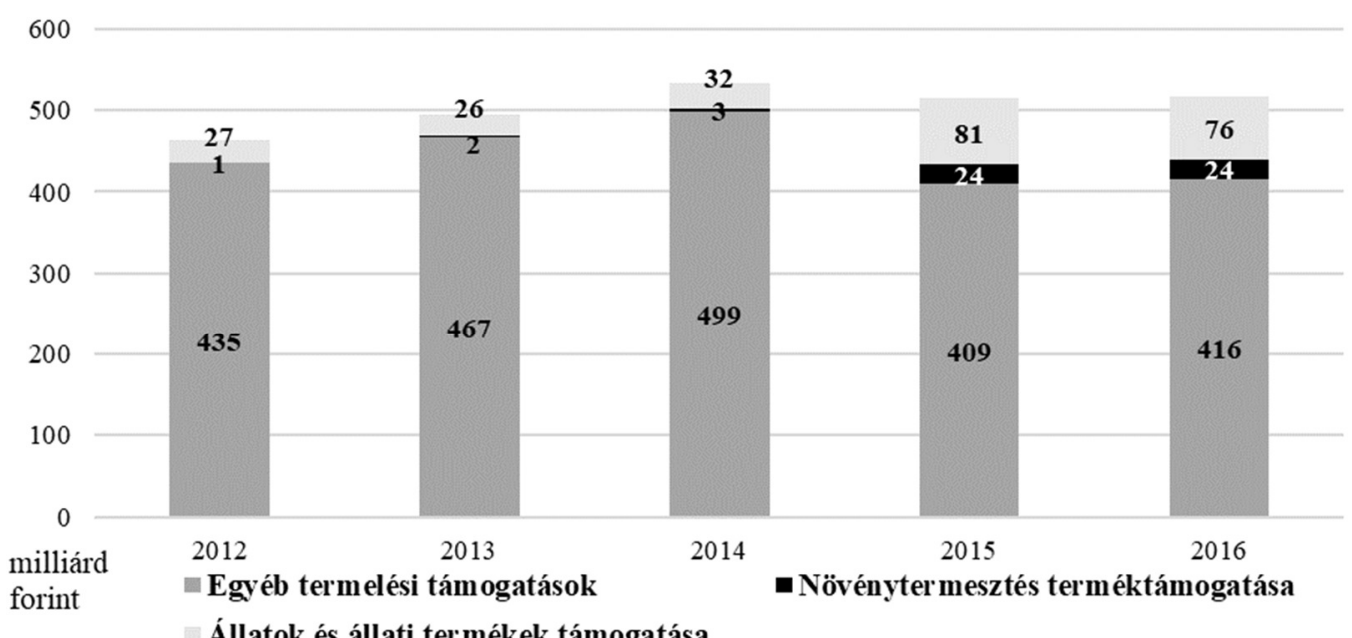

Forrás: KSH (2017) adatai alapján saját szerkesztés 


\subsection{Növekvő jövedelem és csökkenő munkaerő-felhasználás}

A mezőgazdasági számlarendszer elöírásainak megfelelően kimutatott jövedelem egyrészt eredményszemléletü, másrészt azt a jövedelmet is tartalmazza, amely a saját termelésủ mezőgazdasági termékek (illetve házilagos feldolgozásukkal előállított élelmiszerek) fogyasztásából származik a háztartásban. A növénytermesztés terméktámogatása, az állatok és állati termékek terméktámogatása, valamint az egyéb termelési támogatások a bruttó hozzáadott értéket növelik. A jövedelmek forrása a termelői áron kalkulált bruttó hozzáadott érték mellett a termékhez nem köthető támogatások (földalapú és vidékfejlesztési támogatás). Ez az összeg a kibocsátásban nem szerepel, mert közvetlenül a jövedelmet növeli. A termelési tényezők (felhasznált föld, tőke, munkaerő) jövedelme az elmúlt években főként a növénytermesztés hozamaitól és a termelői áraktól függően változott, ami a vállalkozói jövedelem alakulását is meghatározta. Ezzel szemben a felhasználási oldalon szereplö költségek (munkadíj, bérleti díj és kamat) és az értékcsökkenésre elszámolt összeg kevésbé ingadozott.

A termelési tényezők jövedelme 2016-ban 1190 milliárd forint volt. A nettó vállalkozói jövedelem vegyes típusú, mivel a gazdálkodó és családja (a nem fizetett munkaerő) munkájának ellenértékét és a gazdasághoz tartozó föld és tőke hozadékát együttesen mutatja, ennek értéke 2016-ban 702 milliárd forint volt. Magyarország EU-csatlakozás után a mezőgazdasági vállalkozók jövedelmén belül nőtt a támogatások aránya. Az időjárástól függő kibocsátás ingadozása is számottevően befolyásolja a jövedelem alakulását. A jó terméshozamú években a jövedelem összetételében a támogatások szerepe csökken. 2016-ban 73\% volt ez az arány, de a kevésbé jó termést hozó években ennél magasabb arányt tett ki a támogatás vállalkozói jövedelmekben.

Az éves munkaerőegységben (ÉME) kifejezett élőmunka-felhasználás 434 ezer ember mezőgazdasági tevékenységének felelt meg 2016-ban. A 2001 és 2008 közötti időszakban folyamatosan csökkent a munkaráfordítás, de 2009 óta gyakorlatilag stagnált, sőt egyes években még nőtt is a munkaerö-felhasználás. A nem fizetett munkaerő-felhasználás (302 ezer ÉME) 2001 óta folyamatosan visszaesett. A fizetett munkaerö-ráfordítás viszont 2013 óta emelkedett, 2016-ban összesen 132 ezer ÉME volt. A csökkenő nem fizetett munkaerő egy részét fizetett munkaráfordítással pótolták a gazdálkodók (4. ábra). A mezőgazdasági termelők 2016-ban 378 milliárd forintot fizettek ki a munkavállalóknak. 


\section{4. ábra: Munkaerő-felhasználás éves munkaerőegységben 2016-ban}

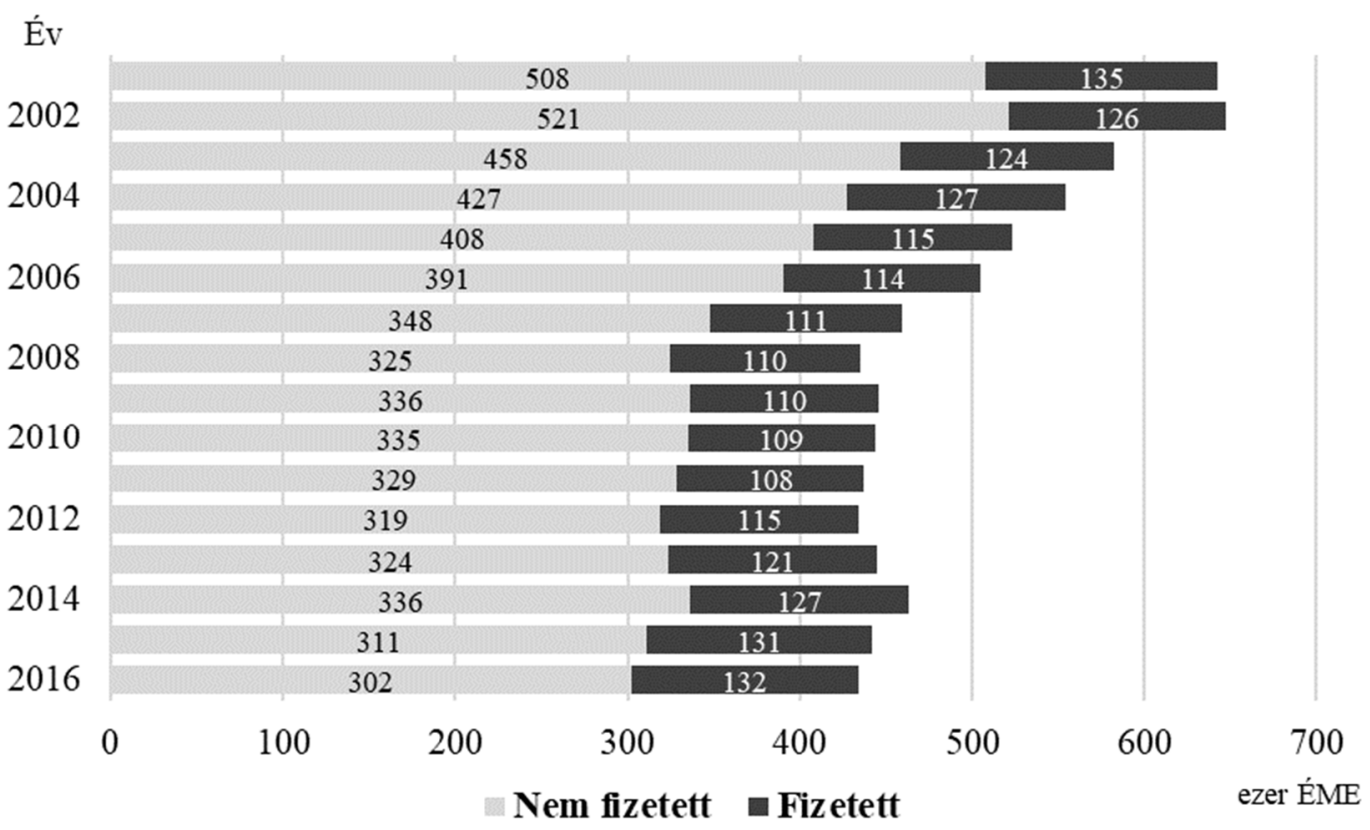

Forrás: KSH (2017) adatai alapján saját szerkesztés

\subsection{A mezőgazdasági termelés alakulása régiónként}

Az egyes régiók mezőgazdasági területének nagysága és termelési adottságai igen eltérőek, ezért mezőgazdasági kibocsátásuk is egyenlőtlen képet mutat. A mezőgazdasági területhez viszonyítva sokkal magasabb aránnyal részesedik az országos gabona-kibocsátásából Dél-Dunántúl, a kertészeti termék-, szőlő-, bor- és gyümölcs kibocsátásából Dél-Alföld és Közép-Magyarország, az élőállat és állatitermék kibocsátásából Közép- és Nyugat-Dunántúl, valamint Észak-Alföld. A hazai gabonaágazat csökkenő versenyképességéhez a nemzetközi piac mellett számos hazai tényező is hozzájárul. A gabona és olajnövény termékpályán a termelői csoportok gazdasági tevékenységének súlya folyamatos csökkenést mutat, pedig a szerveződések, együttműködések gazdaságilag életképes működéséhez megfelelő értékesítési volument kell elérni (Vidékfejlesztési Minisztérium adatai, 2015).

A területileg legnagyobb alföldi régiók szerepe kiemelkedő a mezőgazdasági termelésben: Észak- és Dél-Alföld folyó alapáron a teljes kibocsátás közel felét adják, ezzel szemben a kis területü Észak-Magyarország aránya a kibocsátásban 8,1\%, Közép-Magyarországé pedig 6,9\% volt 2016-ban. A régiók között számottevő az eltérés a növénytermesztés, az állattenyésztés, illetve a szolgáltatás és másodlagos tevékenységek megoszlása alapján. A növénytermesztés aránya ÉszakMagyarországon és Dél-Dunántúlon jelentősen meghaladta az országos átlagot (60\%), míg az állattenyésztés súlya Közép- és Nyugat-Dunántúlon, valamint ÉszakAlföldön felülmúlta az átlagot (32\%) 2016-ban (5. ábra). 


\section{5. ábra: A mezőgazdaság bruttó kibocsátásának megoszlása régiónként 2016-ban}

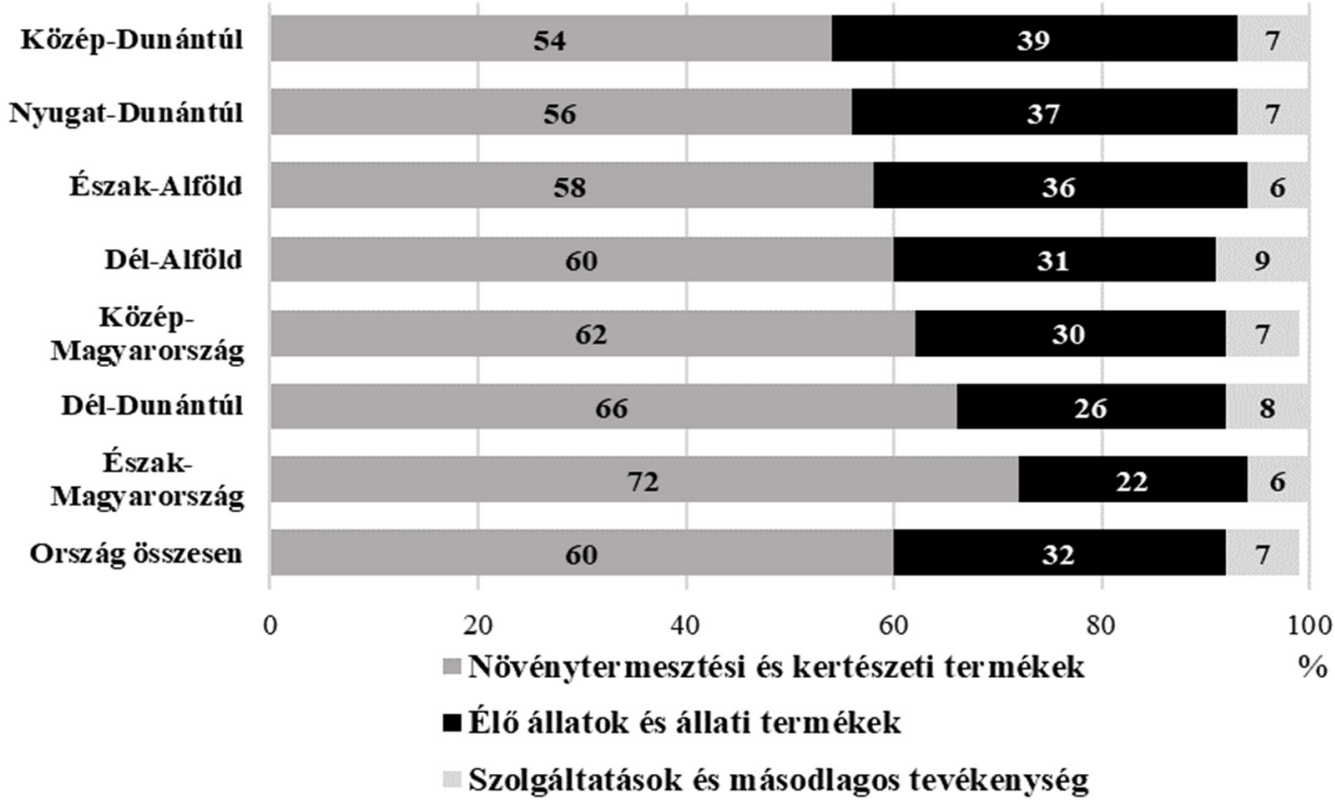

Forrás: KSH (2017) adatai alapján saját szerkesztés

A mezőgazdasági termelés intenzitása (egy hektár mezőgazdasági területre jutó kibocsátás) a kibocsátás emelkedésével és a mezőgazdasági terület stabilitásával összefüggésben emelkedett az elmúlt években. A mezőgazdasági termelés átlag feletti intenzitása Dél-Alföldön, Közép- és Nyugat-Dunántúlon volt megfigyelhető, ugyanakkor jelentősen elmaradt Észak-Magyarországon 2016-ban (6. ábra).

\section{6. ábra: A mezőgazdasági termelés intenzitása régiónként 2016-ban}

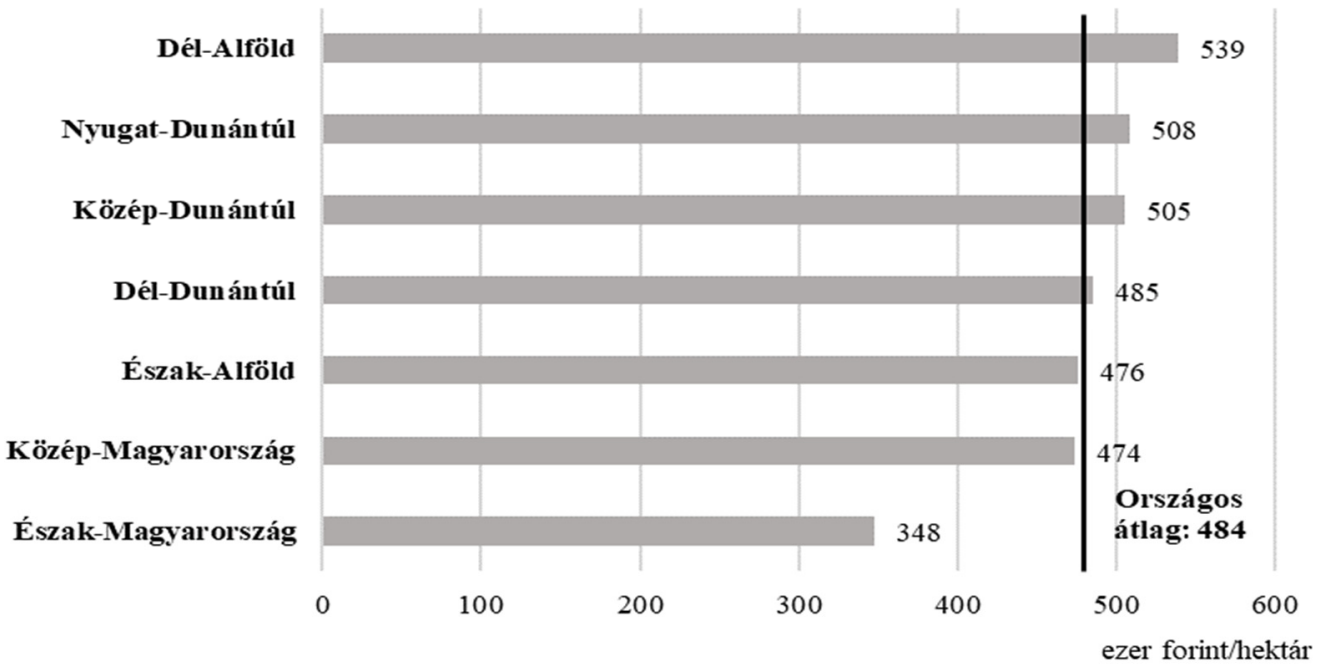

Forrás: KSH (2017) adatai alapján saját szerkesztés 


\section{Következtetések, összegzés, záró megjegyzések, záró gondolatok}

Óriási különbségek vannak az EU tagállamok 276 régiója között az egy före jutó GDP tekintetében vásárlóerő-paritáson számolva, a legszegényebb és a leggazdagabb régiók között tovább mélyült a szakadék a korábbi időszakhoz képest (Eurostat, 2017). Az egyes régiókban a GDP termelést jelentősen befolyásolja az ingázók magas száma, amely jelentős mértékben növeli az adott régiókban az egy főre jutó GDP összeget. 2016-ban Magyarországon vásárlóerő-paritáson számolva az egy főre jutó GDP az uniós átlag 67\%-át érte el. A legmagasabb értéket ismét a Közép-Magyarország régió érte el az uniós átlag 102\%-ával. A központi térség kiemelkedő teljesítménye mögött a főváros gazdasági potenciálja áll. A második helyezett Nyugat-Dunántúl régió, ahol az egy főre jutó GDP az uniós átlag 74\%-át érte el, a harmadik helyen végzett Közép-Dunántúl régióban pedig 64\%-át. A többi négy régióban továbbra is 50\% alatt maradt ez az arány: Dél-Alföldön 48\%, ÉszakMagyarországon 45\%, Dél-Dunántúlon 44\%, Észak Alföldön pedig 43\%. Ez a négy magyar régió az EU 276 régiójából az utolsó 20 legszegényebb régiója között található, vagyis tartósan hátrányos helyzetű térségnek tekinthető (Eurostat, 2018).

A magyar régiók gazdasági helyzete hủen tükrözi az általános gazdaságpolitikai problémákat is. Ezek orvoslása nélkül a hátrányos helyzetű régiók gazdasága sem tud felzárkózni, a mezőgazdaságról nem is beszélve. Magyarország komoly termelékenységi problémával szembesül, sőt a munkaerő-tartalékok elapadásával e probléma egyre súlyosabbá válik. Az exportorientált, jellemzően külföldi tulajdonú vállalkozások termelékenysége jelentős mértékben és tartósan meghaladja a kisebb hazai vállalkozásokét, a magas termelékenységủ szegmensből csak korlátozottan gyürüznek át pozitív külső gazdasági hatások (externáliák). A kkv-k innovációs hajlandósága alacsony, ráadásul Magyarország továbbra is csak visszafogottan használja a digitális technológiákat. A termelékenység növekedését a humán tőke képzettsége is gátolja. A fajlagos munkaköltségek is jelentősen nőttek az utóbbi években. A költség-versenyképesség romlását föleg a bérek emelkedése okozta, ugyanis a termelékenység növekedése csak mintegy felét tette ki a munkavállalói reálbérek növekedésének (Európai Bizottság, 2018). A munkaerőköltségek emelkedése a nagyvállalatok és a külföldi tulajdonú cégek számára valószínüleg nem okoz majd gondot, mivel a bérhányad a müködési területüknek számító feldolgozóiparban sokkal alacsonyabb, mint a gazdaság egészében.

A kevésbé termelékeny mezőgazdasági vállalkozások, különösen a kisgazdaságok számára gondot okozhat a bérek gyors emelkedése, mert kicsi a mozgásterük a munkaerőköltség növelésére. Mivel a bérek egy részét informálisan fizetik ki, a munkaerőköltségek tényleges növekedése a bérstatisztikákban jelzett adatoknál alacsonyabb lehet. A munkaerőhiányhoz hozzájárul, hogy a határon átnyúló munkaerö-migráció és a kedvezőtlen demográfiai folyamatok jól képzett munkaerő-állományt vonnak el a munkaerőpiacról (Hárs, 2016). A migráns munkavállalók jellemzően mind hazai, mind célországi viszonylatban képzettebbek az átlagnál. A felmérések a kivándorlók átlag feletti iskolai végzettségét és a diplomások koncentrációját tükrözik. Magyarország egyre intenzívebben kapcsolódik a migrációs folyamatokba és jelentősebb veszteségeket könyvelhet el 
fiatalabb korcsoportok és a magas iskolai végzettségüek körében (SEEMIG, 2014). Az egyes régiók közötti migráció a jövedelmi különbségek csökkentésének egyik meghatározó és ma igen aktuális módozata. A jobb élet reményében az emberek ma már nemcsak az országon belüli, hanem az egyes országok, illetve földrészek közötti mobilitásban is gondolkodnak. Az EU-nak számolni kell a jövőben a további keletnyugati irányú legális bevándorlással. A demográfiai folyamatok hatására pedig tovább csökken a gazdaságilag aktív népesség. A munkaerőhiány hatására nőnek a bérek, ami viszont visszafogja a külföldi munkavállalást, végső soron a munkaerőhiányt is enyhítheti. A jövőben a reálbérek növekedése várhatóan lelassul, így a fajlagos munkaköltség stabilizálódása várható.

Az alacsonyan képzett munkavállalók alacsony foglalkoztatási rátával és gyenge kilátásokkal, valamint alacsony bérekkel szembesülnek (Európai Bizottság, 2018). Ez a mezőgazdaságra hatványozottan érvényes. A magas képzettségért járó magas bérelőny ellenére kevés felnőtt dönt a továbbképzés mellett. A magasan képzett munkaerő iránti növekvő kereslethez nem illeszkedik a felsőoktatás, így az agrárfelsőoktatás teljesítménye sem. Az agrárképzésre jelentkezők száma folyamatosan csökken, ami csak részben magyarázható demográfiai változásokkal. Az élethosszig tartó tanulásban való felnőtt részvétel előmozdítása a magas képzettségért járó magas bérelőny ellenére továbbra is kihívás, föleg a munkanélküliek körében, miközben a munkáltatók számára egyre nagyobb gondot jelent, hogy szakképzett munkavállalókat találjanak. A jelenlegi helyzet az uniós és nemzeti finanszírozású képzési programokkal javítható.

\section{Köszönetnyilvánítás}

A kutatás az EFOP3.6.3-VEKOP-16-2017-00007 - "Tehetségből fiatal kutató" - A kutatói életpályát támogató tevékenységek a felsőoktatásban. című projekt keretében valósulhatott meg.

\section{Acknowledgements}

Supported by EFOP3.6.3-VEKOP-16-2017-00007 - "Young researchers for talent" - Supporting career in research activities in higher education.

\section{Irodalomjegyzék}

Banai Á., Lang P., Nagy G., Stancsics M. (2017): Hogyan hasznosultak az EU-s források a kkvszektorban?, MNB, Budapest. <https://www.mnb.hu/kiadvanyok/szakmai-cikkek/tovabbiszakmai-cikkek/banai-adam-lang-peter-nagy-gabor-stancsics-martin-hogyan-hasznosultak-azeu-s-forrasok-a-kkv-szektorban> (2018.07.28.)

Botos Sz., Herdon M., Várallyai L. (2015): Readiness for Future Internet Services in Rural Areas. Procedia Eeconomics and Finance, 19: 383-390.

Botos Sz., Felföldi J., Várallyai L., Péntek Á., Szilágyi R. (2018): Analyses the advanced ICT usage of the Hungarian SME sector for preparing a domestic agri-food research abstract. Applied Studies in Agribusiness and Commerce 11 (3-4): 147-154.

EUROSTAT (2017): GDP at regional level. <https://ec.europa.eu/eurostat/statisticsexplained/index.php/GDP_at_regional_level> (2018.07.28.) 
EUROSTAT (2018): Regional gross domestic product (PPS per inhabitant in \% of the EU28 average) by NUTS 2 regions. <https://ec.europa.eu/eurostat/tgm/table.do?tab=table\&init=1\& language $=$ en $\&$ pcode $=\operatorname{tgs} 00006 \&$ plugin $=1>(2018.07 .28$. $)$

EURÓPAI BIZOTTSÁG (2018): Bizottsági szolgálati munkadokumentum, 2018. évi országjelentés - Magyarország, SWD(2018) 215 final. <https://ec.europa.eu/info/sites/info/files/2018european-semester-country-report-hungary-hu.pdf $>$ (2018.07.28.)

Gazdag L. (2003): A XXI. század multifunkcionális mezőgazdaságának stratégiái. Gazdaság és Társadalom, 2: 39-66.

Hárs Á. (2016): Elvándorlás, bevándorlás és a magyar munkaerőpiac. Jelenségek, hatások, lehetőségek. Társadalmi Riport, TÁRKI, Budapest. <http://www.tarki.hu/hu/publications/SR/ 2016/12hars.pdf> (2018.07.28.)

Herdon M., Botos Sz., Várallyai L. (2015): Decreasing the Digital Divide by Increasing E-Innovation and E-Readiness Abilities in Agriculture and Rural Areas. International Journal of Agricultural and Environmental Information Systems, 6 (1): 1-18.

Kapronczai I. (szerk.), Korondiné Dobolyi E., Kovács H., Kürti A., Varga E., Vágó Sz. (2005): A mezögazdasági termelők alkalmazkodóképességének jellemzői (Gazdálkodói válaszok időszerü kérdésekre). Agrárgazdasági Tanulmányok, 6. Budapest.

Kopint-Tárki (2017): Survey and Study Paper on the Hungarian Investment Environment (Felmérés és tanulmány a magyarországi beruházások környezetéről). Kopint-Tárki, Budapest.

KPMG-GKI (2017): A magyarországi európai uniós források felhasználásának és hatásainak elemzése. <https://www.palyazat.gov.hu/magyarorszagi_europai_unios_forrasok_elemzese> (2018.07.28.)

KSH (2017): Mezőgazdasági számlarendszer, 2016 - Központi Statisztikai Hivatal, <https://www.ksh.hu/docs/hun/xftp/idoszaki/mgszlak/mgszlak16.pdf> (2018.07.28.)

KSH (2018): A mezőgazdaság szerepe a nemzetgazdaságban, 2017. <http://www.ksh.hu/docs/ hun/xftp/idoszaki/mezo/mezoszerepe17.pdf> (2018.07.28.)

Popp J., Fazakas P., Hollósi D., Oláh J. (2017a): A versenyképes mezőgazdaság, a földár és a föld jövedelemtermelő képesség összefüggései. Gazdálkodás, 6 (61): 491-504.

Popp J., Harangi-Rákos M., Nagy A., Oláh J. (2017b): A búza és kukorica termékpálya nemzetközi kilátásai. A Falu, 2017. Tél, 32 (4): 43-57.

Popp J., Potori N., Udovecz G. (szerk.) (2007): Alkalmazkodási kényszerben a magyar mezőgazdaság. Folytatódó lemaradás vagy felzárkózás? Agrárgazdasági Tanulmányok, 7. Budapest.

SEEMIG (Managing Migration in South East Europe) (A délkelet-európai migráció kezelése) (2014): Helyzetkép a magyarországi elvándorlásról, KSH. <https://www.ksh.hu/docs/szolgaltatasok/ sajtoszoba/seemig_sajto_reszletes.pdf> (2018.07.28.)

Udovecz G. (2007): Az Európai Agrárpolitika eszményei és realitásai. Gazdálkodás, 51 (20): 2-10.

Vidékfejlesztési Minisztérium adatai (2015): KSH, 2015 B/3566. számú jelentés az agrárgazdaság 2013. évi helyzetéröl, I-II. kötet 